\title{
Redistribution and Stabilization of Cell Surface Glutamate Receptors during Synapse Formation
}

\author{
Andrew L. Mammen, ${ }^{1,2}$ Richard L. Huganir, ${ }^{1,2}$ and Richard J. O'Brien ${ }^{1,2,3}$ \\ ${ }^{1}$ Howard Hughes Medical Institute, and Departments of ${ }^{2}$ Neuroscience and ${ }^{3}$ Neurology, Johns Hopkins University School \\ of Medicine, Baltimore, Maryland 21205
}

\begin{abstract}
Although the regulation of neurotransmitter receptors during synaptogenesis has been studied extensively at the neuromuscular junction, little is known about the control of excitatory neurotransmitter receptors during synapse formation in central neurons. Using antibodies against extracellular $\mathrm{N}$-terminal ( $\mathrm{N}$ GluR1) and intracellular C-terminal (C-GluR1) domains of the AMPA receptor subunit GluR1, combined with surface biotinylation and metabolic labeling studies, we have characterized the redistribution and metabolic stabilization of the AMPA receptor subunit GluR1 during synapse formation in culture. Before synapse formation, GluR1 is distributed widely, both on the surface and within the dendritic cytoplasm of these neurons. The diffuse cell surface pool of receptor appears to be mobile within the membrane and can be induced to cluster by the
\end{abstract}

addition of N-GluR1 to live neurons. As cultures mature and synapses form, there is a redistribution of surface GluR1 into clusters at excitatory synapses where it appears to be immobilized. The change in the distribution of GluR1 is accompanied by an increase in both the half-life of the receptor and the percentage of the total pool of GluR1 that is present on the cell surface. Blockade of postsynaptic AMPA and NMDA receptors had no effect on the redistribution of GluR1. These results begin to characterize the events regulating the distribution of AMPA receptors and demonstrate similarities between synapse formation at the neuromuscular junction and at excitatory synapses in cultured neurons.

Key words: GluR1; synaptogenesis; spinal cord; metabolism; glutamate receptors; rat; tissue culture
The processes involved in the generation and maintenance of synapses are critical for neuronal development and synaptic plasticity. To date, information regarding the regulation of neurotransmitter receptors during synapse formation has largely been derived from studies of the developing vertebrate neuromuscular junction (Hall and Sanes, 1993). On the surface of embryonic myotubes before synapse formation, acetylcholine receptors (AChRs) are distributed diff usely at a density of $10^{2} / \mu \mathrm{m}^{2}$. Under the influence of molecules secreted by the motor nerve terminal, AChRs become highly enriched at sites of nerve-muscle contact $\left(\sim 10^{4} \mathrm{AChRs} / \mu \mathrm{m}^{2}\right)$ and depleted at extrajunctional areas (Anderson and Cohen, 1977; Frank and Fischbach, 1979; Salpeter and Harris, 1983; Salpeter and Marchaterre, 1988). The synaptic enrichment of AChRs is attributable to the clustering of preexisting extrasynaptic receptors and the directed insertion of newly synthesized receptors (Role et al., 1985). In addition to the dramatic changes in receptor localization that accompany synaptogenesis at the neuromuscular junction, the metabolic half-life of receptors increases from 1 to $10 \mathrm{~d}$ (Berg and Hall, 1975b; Reiness and Weinberg, 1981; Steinbach, 1981).

Ionotropic glutamate receptors (GluRs) mediate excitatory synaptic transmission between neurons in the CNS. These receptors have been cloned and divided into AMPA, kainate, and NMDA subclasses on the basis of their electrophysiological and pharmacological properties (Seeburg, 1993; Hollman and Heinemann, 1994). Each subclass of ionotropic GluRs includes several distinct subunits that exist as heteromeric complexes. Ionto-

Received February 28, 1997; revised June 2, 1997; accepted June 10, 1997.

Correspondence should be addressed to Dr. Richard Huganir, Howard Hughes Medical Institute, PCTB 900, Johns Hopkins Medical School, 725 N. Wolfe Street, Baltimore, MD 21205.

Copyright (C) 1997 Society for Neuroscience $0270-6474 / 97 / 177351-08 \$ 05.00 / 0$ phoretic mapping, immunocytochemistry, and immunoelectron microscopy have demonstrated that these receptors are localized at excitatory synapses (for review, see Ehlers et al., 1996). Little is known, however, about the mechanisms regulating clustering and maintenance of GluRs at central synapses.

We have previously characterized the development and subunit composition of GluR clusters in cultured spinal neurons (O'Brien et al., 1997). Over a period of $10 \mathrm{~d}$, the AMPA receptor subunit GluR1, visualized with an antibody that recognizes the intracellular $\mathrm{C}$ terminus, changes its distribution from diffuse to highly clustered at sites of synaptic contact, similar to the pattern seen with GABA $_{\mathrm{A}}$ (Killisch et al., 1991) and glycine receptors (Bechade et al., 1996). Here, we use an extracellular antibody to GluR1 to study the distribution of surface receptors during synaptogenesis in the same system. When applied to live neurons, the bivalent antibody induces the aggregation of extrasynaptic receptors, rendering them easily visualizable, while simultaneously staining preexisting synaptic clusters. We demonstrate that a pool of mobile, extrasynaptic receptors is expressed on the surface of immature dendrites, which diminishes as GluR1 redistributes to synapses. Coincident with the redistribution of GluR1 to synapses, there is a metabolic stabilization of AMPA receptors, evidenced by an increase in their half-life, determined both by surface biotinylation and metabolic labeling. In addition to the surface receptors, a second pool of GluR1 exists within the cytoplasm of dendrites before and after the period of maximal synaptogenesis. The relative distribution of GluR1 between the surface and cytoplasmic pools of receptors also changes with time, because of an increase in the number of surface receptors.

\section{MATERIALS AND METHODS}

Generation of N-terminal GluR1 (N-GluR1). N-GluR1 was made by injecting rabbits with the synthetic peptide KQWRTSDSRDHTRVD- 
WKRPK (Molnar et al., 1994) coupled to albumin. The antisera was affinity-purified against the same peptide coupled to thyroglobulin, using $\mathrm{MgCl}_{2}$ for elution. Fab fragments of $\mathrm{N}-\mathrm{GluR} 1$ were generated using papain according to the Pierce (Rockford, IL) protocol (no. 44885). Each batch of Fab fragments was tested for its ability to detect receptor clusters, using C-terminal GluR1 (C-GluR1) as a control.

Patching of surface GluRs. Cultures of embryonic day 19 to postnatal day 3 rat spinal cords were prepared as described in O'Brien et al. (1997). At the appropriate times in culture, the antibody N-GluR1 was added to growth medium at a concentration of $2 \mu \mathrm{g} / \mathrm{ml}$ for $90 \mathrm{~min}$. Cultures were then rinsed in four changes of HBSS and fixed and processed for immunohistochemistry as described (O'Brien et al., 1997). Fab fragments of N-GluR1 were used at a concentration of $10 \mu \mathrm{g} / \mathrm{ml}$. In cases in which C-GluR1 and C-GluR2/3 antibodies were used jointly with N-GluR1, the C-terminal antibodies were primarily labeled with $\mathrm{Cy} 3$ (CyDye Kit, Amersham, Arlington Heights, IL). Immunohistochemical control experiments consisted of incubating a $20 \times$ concentrate of either the $\mathrm{N}$ - or C-GluR1 antibodies with appropriate peptide $(0.2 \mathrm{mg} / \mathrm{ml})$ for $1 \mathrm{hr}$ at room temperature. This solution was then diluted 1:20 to its final concentration and added to the coverslips as above.

Surface half-life experiments. Spinal cord cultures were washed once with $\mathrm{PBS} / \mathrm{Ca}^{2+} / \mathrm{Mg}^{2+}(10 \mathrm{~mm}$ phosphate buffer, $2.7 \mathrm{mM} \mathrm{KCl}, 137 \mathrm{~mm}$ $\left.\mathrm{NaCl}, 1 \mathrm{mM} \mathrm{CaCl}{ }_{2}, 0.5 \mathrm{~mm} \mathrm{MgCl}_{2}, \mathrm{pH} 7.4\right)$ at $37^{\circ} \mathrm{C}$ and then cooled gradually to $4^{\circ} \mathrm{C}$ before they were washed twice with cold $\mathrm{PBS} / \mathrm{Ca}^{2+}$ $\mathrm{Mg}^{2+}$. Cultures were incubated with $2 \mathrm{ml}$ of biotinylation reagent (1 $\mathrm{mg} / \mathrm{ml}$ NHS-SS-biotin in PBS/C $\mathrm{Ca}^{2+} / \mathrm{Mg}^{2+}$ ) while being shaken gently at $4^{\circ} \mathrm{C}$ for $12 \mathrm{~min}$, and then washed three times with cold $\mathrm{PBS} / \mathrm{Ca}^{2+} / \mathrm{Mg}^{2+}$ including $0.1 \%$ BSA. Growth media was then added back, and the plates were returned to the $5 \% \mathrm{CO}_{2}$ incubator at $37^{\circ} \mathrm{C}$. Cell extracts were collected at regular intervals beginning $30 \mathrm{~min}$ after return of the cultures to the incubator by washing the plates with PBS and scraping the cells into $166 \mu \mathrm{l}$ of warm precipitation buffer (PB; $10 \mathrm{mM} \mathrm{NaPO}_{4}, \mathrm{pH} 7.4$, $5 \mathrm{~mm}$ EDTA, $5 \mathrm{~mm}$ EGTA, $100 \mathrm{~mm} \mathrm{NaCl}, 1 \mathrm{~mm} \mathrm{Na} \mathrm{VO}_{4}, 10 \mathrm{~mm}$ sodium pyrophosphate, $50 \mathrm{~mm} \mathrm{NaF}$, and $10 \mu / \mathrm{ml}$ aprotinin) with $1 \%$ SDS (PB/SDS) and $10 \mathrm{~mm}$ lysine. The resulting solution was then diluted with $833 \mu \mathrm{l}$ of cold PB with $1 \%$ Triton X-100 (PB/Triton) and $10 \mathrm{~mm}$ lysine, sonicated, and microfuged for $20 \mathrm{~min}$ at 14,000 rpm. The supernatants, which include $>95 \%$ of the total GluR1, were frozen at $-80^{\circ} \mathrm{C}$. To precipitate biotinylated proteins, samples were thawed, mixed with $200 \mu \mathrm{l}$ UltraLink immobilized streptavidin beads (Pierce), and rotated for $2 \mathrm{hr}$ at $4^{\circ} \mathrm{C}$. The beads were washed twice with $\mathrm{PB} /$ Triton, twice with $\mathrm{PB} /$ Triton including $600 \mathrm{mM} \mathrm{NaCl}$, and twice with PB alone. After the addition of SDS-PAGE sample buffer to the beads, the resulting slurry was boiled for $3 \mathrm{~min}$. The biotinylated proteins were resolved by SDSPAGE, transferred to Immobilon-P (Millipore, Bedford MA), and probed with either the C-GluR1 or neuronal glutamate transporter antibodies. Proteins were visualized with enhanced chemiluminescence (ECL) (Amersham). The volume of sample loaded for each half-life experiment was adjusted such that all time points would be within the linear range of the film. Serial dilutions of the $t=0$ sample were run on each gel to provide a standard curve for each experiment.

Surface expression experiments. Cell extracts were prepared from spinal cord cultures immediately after the biotinylation reaction described above by washing the plates with $\mathrm{PB} / 1 \% \mathrm{BSA}$, adding $166 \mu \mathrm{l}$ of PB/SDS, and diluting with $833 \mu \mathrm{l}$ of $\mathrm{PB} /$ Triton. These $1 \mathrm{ml}$ samples were mixed with $200 \mu \mathrm{l}$ of streptavidin beads and rotated at $4^{\circ} \mathrm{C}$ for $2 \mathrm{hr}$. From this slurry, $240 \mu \mathrm{l}(20 \%$ of total) was removed and added to $100 \mu \mathrm{l}$ of $3 \times$ sample buffer. The beads $(80 \%$ of total) were precipitated from the remaining slurry, and the supernatant was added to $400 \mu \mathrm{l}$ of $3 \times$ sample buffer. The beads were washed in $800 \mu \mathrm{l}$ each of PB/Triton, PB/Triton with $600 \mathrm{~mm} \mathrm{NaCl}$, and PB alone. These washes were saved and added to $400 \mu \mathrm{l}$ of $3 \times$ sample buffer. The biotinylated proteins were eluted from the streptavidin beads into $1200 \mu \mathrm{l}$ of $1 \times$ sample buffer. All samples were boiled for $3 \mathrm{~min}$ and spun in a microcentrifuge before an equal volume of each was loaded per lane. Serial dilutions of the total extract were run on each gel to generate a standard curve for each experiment. After transfer of the proteins, the immunoblots were probed with C-GluR1, stripped, and reprobed with tubulin antibody.

Efficiency of biotinylation. In experiments designed to determine the efficiency of biotinylation, cells were prepared for biotinylation as described, scraped into the biotinylation reagent, sonicated, and spun for 15 min at $100,000 \times g$; the pellets were washed three times with $\mathrm{PBS} / \mathrm{Ca}^{2+} /$ $\mathrm{Mg}^{2+}$ including $0.1 \%$ BSA. Detergent-soluble extracts of the pellets were prepared as described above, by adding PB/SDS and diluting with PB/ Triton. These extracts were sonicated and spun in a refrigerated micro- centrifuge at $14,000 \times g$ for $15 \mathrm{~min}$, and the supernatants were processed as described above for the surface expression experiments.

Quantitation of Western blots. All proteins were visualized by ECL and analyzed using a Molecular Dynamics Personal Densitometer SI. Protein band intensity was quantitated using ImageQuant. A standard curve was generated for each film, such that band intensity could be expressed as a percentage of the biotinylated material at $t=\mathrm{O}$ (for the half-life experiments) or a percentage of the total extract (for the surface expression experiments). To calculate half-lives, we plotted the natural logarithm of the percentage of protein remaining as a function of time and found the slope of the resulting regression line. Assuming first-order decay kinetics, the half-life is equal to $\ln 2 /$ slope.

Metabolic labeling and half-life determination of total GluR1. The growth media from spinal cord cultures was removed and replaced with $1 \mathrm{ml}$ of methionine and cysteine-free media containing $0.8 \mathrm{mCi}$ Tran ${ }^{35} \mathrm{~S}$ label. Cells were incubated in this media for $30 \mathrm{~min}$, washed with PBS, and then returned to the incubator in their original growth media. At various time points, cell extracts were prepared by adding $1 \mathrm{ml}$ of ice-cold lysis buffer (50 mM sodium phosphate, $\mathrm{pH} 7.5$, with $1.0 \%$ Triton X-100, $0.5 \%$ deoxycholate, $0.2 \%$ SDS, $50 \mathrm{~mm} \mathrm{NaF}, 10 \mathrm{~mm}$ sodium pyrophosphate, $5 \mathrm{~mm}$ EDTA, $5 \mathrm{~mm}$ EGTA, and $10 \mathrm{U} / \mu \mathrm{l}$ aprotinin) to the plates. The cells were scraped off the plates, transferred to a microfuge tube, mixed by inversion, and centrif uged at $4^{\circ} \mathrm{C}$ for $15 \mathrm{~min}$ at $15,000 \times \mathrm{g}$. The supernatants were stored at $-80^{\circ} \mathrm{C}$ before use. Once all samples had been collected, $100 \mu \mathrm{l}$ of a 1:1 slurry of protein A-Sepharose CL-4B (Pharmacia, Piscataway, NJ) and lysis buffer with $1 \%$ bovine serum albumin was added to each tube. After rotating for $1 \mathrm{hr}$ at $4^{\circ} \mathrm{C}$, the mixtures were spun at $2000 \times g$ for $2 \mathrm{~min}$, and the supernatants were transferred to microfuge tubes containing $150 \mu \mathrm{l}$ of protein A-Sepharose that had been prebound with $4 \mu \mathrm{l}$ of crude C-GluR1 antibody. After rotating for $2 \mathrm{hr}$ at $4^{\circ} \mathrm{C}$, the beads were washed sequentially with the following solutions: lysis buffer alone (twice); lysis buffer with $750 \mathrm{~mm} \mathrm{NaCl}$ (three times); 10 mM sodium phosphate, pH 7.5, with $0.1 \%$ Triton X-100, $50 \mathrm{~mm} \mathrm{NaF}$, and 5 mM EDTA (twice). After removal of the final wash, SDS-PAGE sample buffer was added directly to the beads to elute antibody-bound GluR1. Eluted proteins were boiled for $3 \mathrm{~min}$ before being loaded on $7.5 \%$ polyacrylamide gels. After completion of electrophoresis, gels were dried and visualized on a Molecular Dynamics Phosphoimager. Half-lives were calculated after quantitation of labeled GluR1 in each sample using ImageQuant software.

\section{RESULTS}

\section{An N-terminal antibody induces patches of surface GluR1}

To study the distribution of surface GluRs during synaptogenesis, we generated an antibody against an N-terminal domain of GluR1 (amino acids 251-269) (Molnar et al., 1994), a region thought to be on the extracellular face of the plasma membrane (Hollmann et al., 1994; Roche et al., 1994). This antibody, N-GluR1, recognized a number of proteins in total extracts of cultured spinal cord neurons (Fig. 1 $A$ ); however, when used to probe a sample including only cell surface proteins that had been biotinylated and precipitated with streptavidin beads, N-GluR1 recognized a single predominant protein. This protein comigrated with GluR1, as recognized by our previously described intracellular antibody, C-GluR1 (Blackstone et al., 1992). Presumably, the additional species recognized by N-GluR1 in total extracts of spinal cord neurons are intracellular proteins. When N-GluR1 was added to mature, live spinal cord cultures for $1 \mathrm{hr}$ and then processed for double labeling with C-GluR1 as described in Materials and Methods, N- and C-GluR1 staining completely colocalized (Fig. $1 B)$. Preincubation of N-GluR1 with its cognate peptide completely abolished its immunoreactivity (Fig. 1C). Studies with HEK-293 cells transiently transfected with recombinant GluR1 gave similar results (data not shown). These results confirm the specificity of the N-GluR1 antibody when used for staining surface GluR1 receptors in live neurons.

In our previous study, we examined the distribution of GluR1 in spinal cord neurons using the C-terminal antibody C-GluR1, 


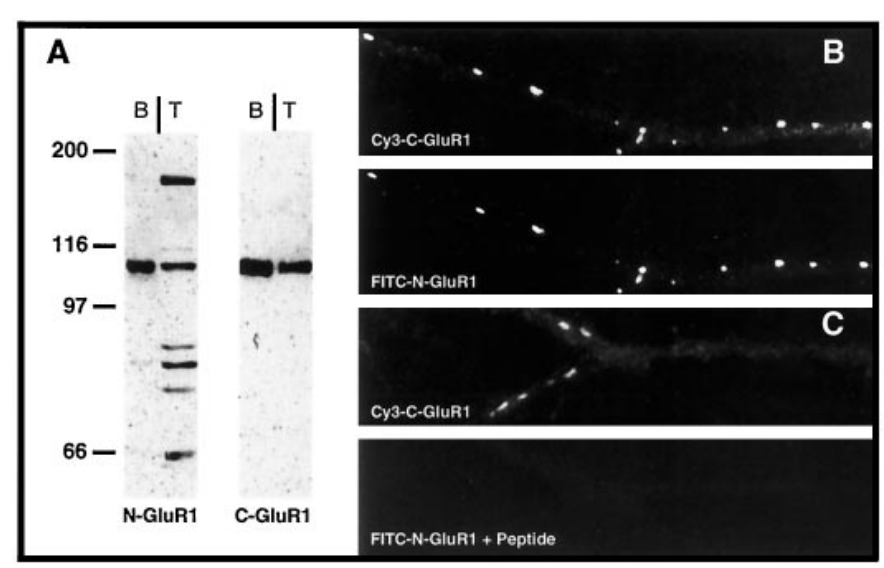

Figure 1. Characterization of the N-GluR1 antibody. An antibody was raised against an $\mathrm{N}$-terminal region of GluR1 as described in Materials and Methods. $A$, Immunoblots of either total $(T)$ or biotinylated- and streptavidin-immunoprecipitated $(B)$ spinal cord cultures were probed with antibodies to either N-GluR1 or C-GluR1. Although N-GluR1 recognized several proteins, in addition to GluR1, in total extracts of spinal cord, there was only a single, appropriately sized protein in the pool of surface molecules. $B, C$, Live cultures of spinal cord neurons were labeled with N-GluR1 $(B)$ or N-GluR1 plus peptide $(0.1 \mathrm{mg} / \mathrm{ml})(C)$ for $1 \mathrm{hr}$ and then fixed and labeled with C-GluR1 as described in Materials and Methods. Surface labeling with N-GluR1 completely overlapped with C-GluR1 and was completely blocked by peptide.

which in fixed and permeabilized cells detects receptors both on the surface and within the cytoplasm of dendrites. Before synaptogenesis, GluR1 staining was distributed diffusely throughout the cell. As synapses formed over the first $10 \mathrm{~d}$ in vitro, GluR1 clusters appeared only at sites of synaptic vesicle accumulation, presumably representing synaptic contacts. In contrast, when N-GluR1 was added to live spinal cord cultures before synaptogenesis (days 3 and 4 in vitro), a significant and widely distributed population of nonsynaptic, surface receptors was observed in the form of microaggregates (Fig. 2A). These aggregates likely represent antibody-induced receptor patching, because only a diff use staining pattern was seen when neurons were incubated with a Fab fragment of N-GluR1 (Fig. $2 E-H)$ or when cells were fixed but not permeabilized before the addition of N-GluR1 (data not shown). The specificity of the N-GluR1 surface staining at these sites is revealed by corresponding patches detected by the $\mathrm{C}$-terminal antibody C-GluR1 (Fig. 2B). These antibody-induced clusters of GluR1 are not found at sites of cell-cell contact (Fig. 2D,L), nor do they colocalize with the synaptic vesicle protein synaptophysin (Fig. $2 C, K$ ), indicating that they are not associated with synapses. To confirm that the patches induced by N-GluR1 were indeed present on the cell surface, we stained N-GluR1induced patches with an FITC-labeled secondary antibody without previous permeabilization (Fig. 2I). Under these conditions, staining for intracellular epitopes such as C-GluR1 was absent (Fig. 2J). The surface population of receptors detected with N-GluR1 represents only a fraction of the total dendritic pool of GluR1. A $1 \mathrm{hr}$ incubation with N-GluR1 appeared to patch all the surface GluR1 (Fig. 2A) but left a significant portion of the total pool, defined by C-GluR1, unclustered (Fig. 2B). This latter population likely reflects a pool of GluR1 within the dendritic cytoplasm but not on the surface (see below).

\section{Redistribution of GluR1 to synapses during neuronal maturation}

The pool of mobile, extrasynaptic, surface GluR1 decreased dramatically as neurons matured during the first 2 weeks in culture. As shown in Figure 3, antibody-induced extrasynaptic patches of surface GluR1 (Fig. $3 A-C$ ) are not seen in mature cultures (Fig. $3 D-F$ ). In contrast, at these latter time points, receptors were seen to localize primarily at sites of presynaptic vesicle accumulation, defined by the presence of the synaptic vesicle protein synaptophysin. Because fixation of the mature cultures before staining with N-GluR1 resulted in an identical distribution, with clustered receptor observed only at synapses (data not shown), we conclude that these synaptic clusters are immobile and not antibody-induced. In Figure 4, the replacement of the diffuse, mobile receptor pool by a largely synaptic and immobile pool is evaluated semiquantitatively by examining a large number of cells from cultures of various ages. GluR1positive neurons, which make up $70 \%$ of the total population, were categorized as "extrasynaptic" if they had mostly N-GluR1induced, nonsynaptic receptor patches, "synaptic" if they had mostly synaptophysin-associated receptor clusters, and "transitional" if they had both synaptic and nonsynaptic GluR1 clusters (see Figure 4 legend for definitions). On day 3 in vitro, $72 \%$ of neurons had predominantly extrasynaptic receptors, $8 \%$ had predominantly synaptic receptors, and $19 \%$ were transitional. By day 11 the distribution had changed to $0 \%$ extrasynaptic, $80 \%$ synaptic, and $20 \%$ transitional. Thus, during the maturation of spinal cord neurons in culture, there is a significant redistribution of surface GluR1 to synapses, which is nearly complete by day 11 . Growing these cultures in CNQX $(10 \mu \mathrm{M})$ and APV (1 mM), concentrations sufficient to completely block synaptic transmission (O'Brien et al., 1997), had no effect on GluR1 redistribution.

As noted above, little surface staining of GluR1 appeared outside of antibody-induced patches on day 4, or outside synaptic contacts on day 11 . In contrast, C-GluR1, which stains both intracellular and plasma membrane GluR1, recognized a significant pool of diff use GluR1 throughout the dendrite and cell body at both time points (Fig. 3B,E), even after the surface receptors were patched with N-GluR1. Thus, we conclude that although there is a decrease in extrasynaptic surface GluR1 as synapses form, there remains a substantial pool of diffuse GluR1 located throughout the dendritic cytoplasm. The specificity of this diffuse staining for GluR1 was demonstrated in two ways (Fig. 5). First, in the $30 \%$ of neurons that were GluR 1 immunonegative both at the cell body and at synaptic contacts, there was little diffuse dendritic staining (Fig. 5B, open arrows). Second, nearly all the diff use dendritic stain could be abolished by preincubation with the appropriate peptide (Fig. 5C,D). Therefore, before synaptogenesis two pools of GluR1 exist in cultured dendrites: one diff use and freely mobile on the cell surface, and another, larger pool (see below) within the cytoplasm.

\section{Distribution of GluR1 on the surface of isolated neurons}

To study the distribution of surface GluR1 in neurons devoid of their normal synaptic input, we grew single, isolated spinal cord neurons on islands of glia for up to 2 weeks in vitro (Segal and Furshpan, 1990). In our accompanying paper in this issue (O'Brien et al., 1997), we showed that $70 \%$ of these isolated neurons express GluR1 but that only $30 \%$ of these have GluR1 clusters at sites of autaptic connections. These GluR1-expressing isolated neurons continued to have N-GluR1-clusterable, extra- 

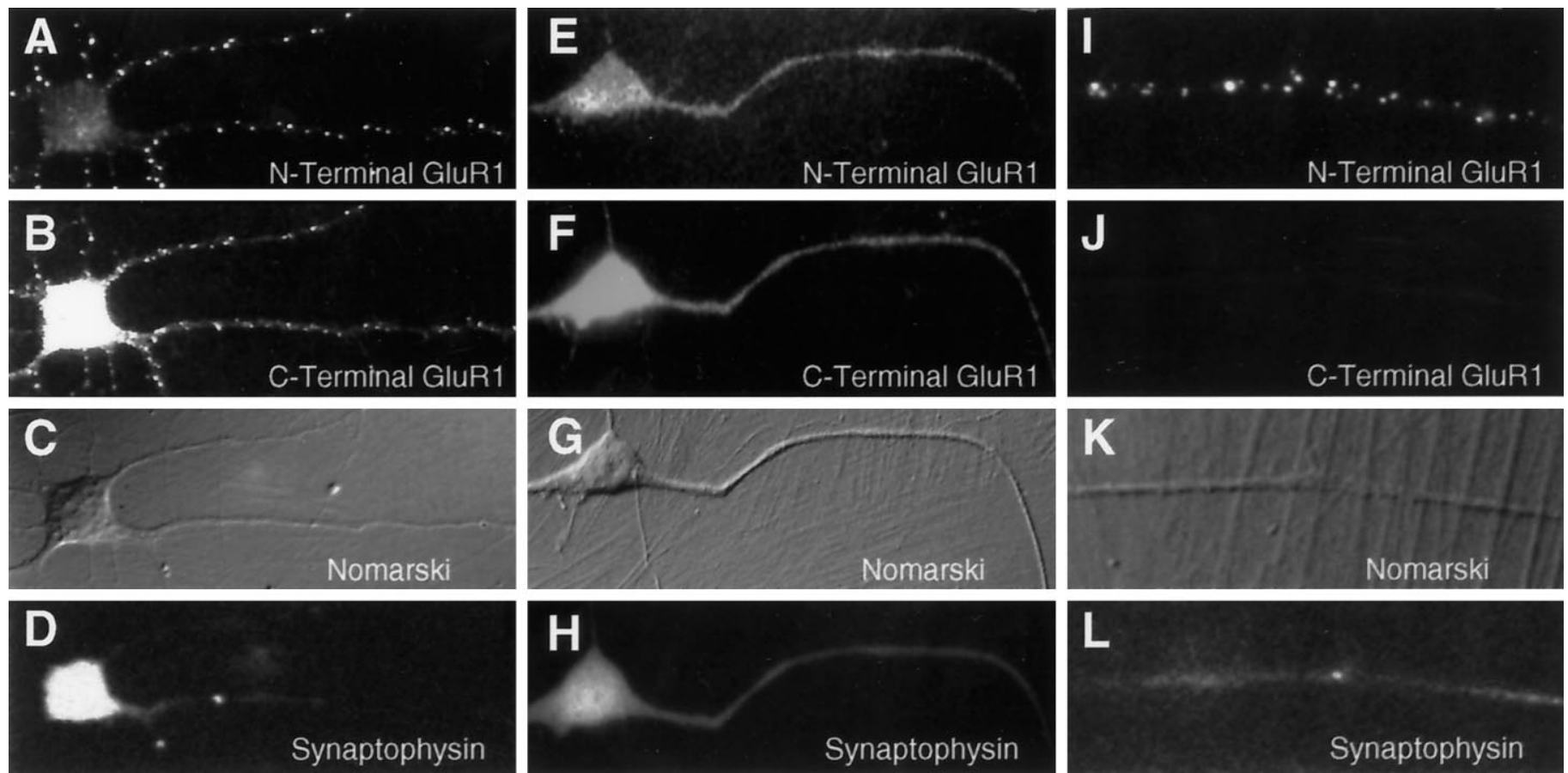

Figure 2. Induction of extrasynaptic receptor patches by the N-GluR1 antibody. Live, 3-d-old cultures of spinal cord neurons were incubated with whole N-GluR1 $(A-D, I-L)$ or a Fab fragment of N-GluR1 $(E-H)$ and then fixed and processed as described. Antibody-induced surface patches of N-GluR1 $(A)$, which are not seen with a Fab fragment of N-GluR1 $(E)$, have corresponding clusters of C-terminal GluR1 staining (compare $B$ with $F$ ). In nonpermeabilized neurons $(I)$ surface $\mathrm{N}$-GluR1 staining is observed, whereas $\mathrm{C}$-terminal staining is not detectable. The nonsynaptic location of this staining is confirmed by the lack of associated synaptophysin stain $(D, H, L)$, and the absence of cell-cell contact at these sites $(C$, $G, K)$.
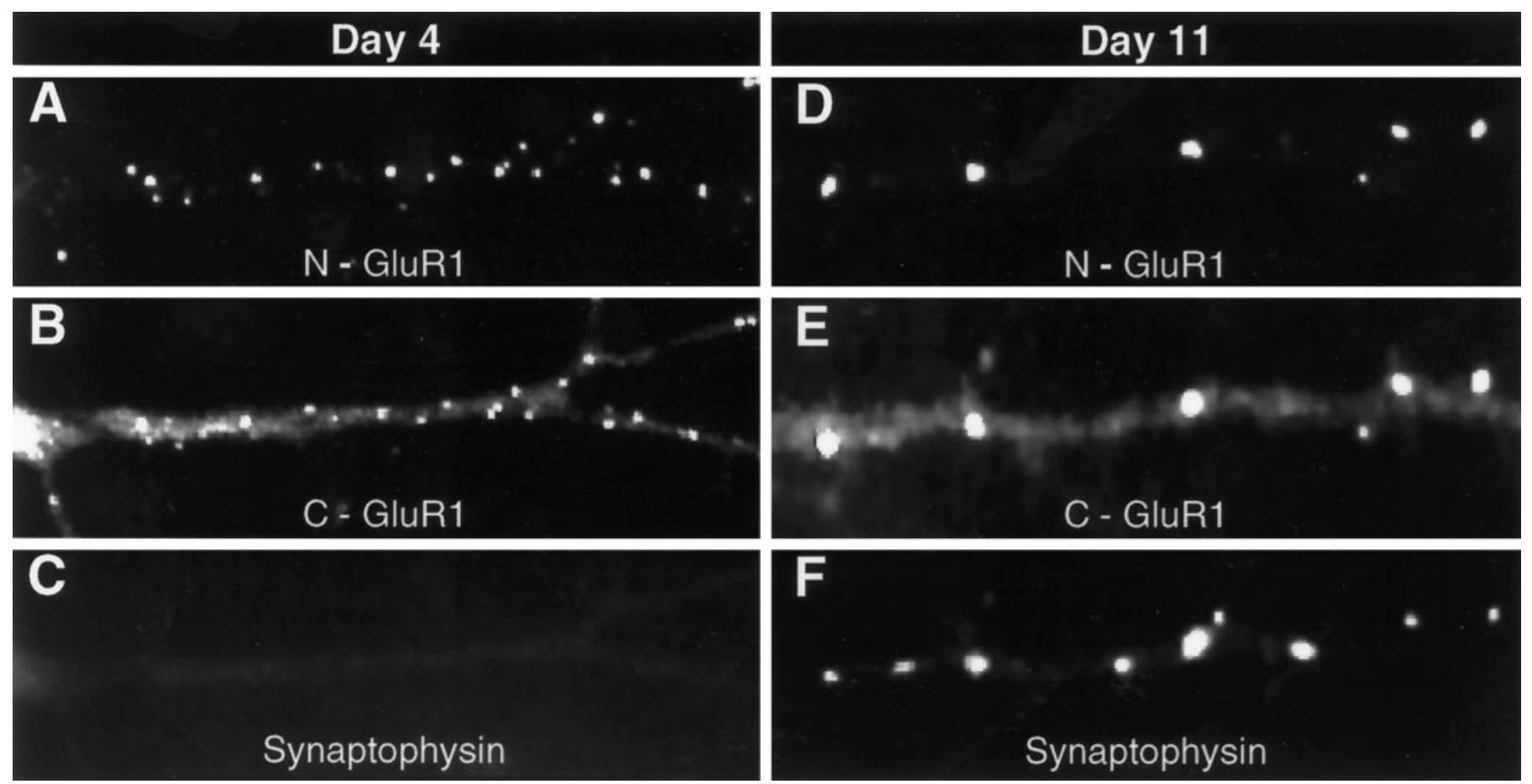

Figure 3. The distribution of surface GluR1 changes over time in culture. Antibody-induced, nonsynaptic patches of GluR1 are abundant on the dendrites of neurons after $4 \mathrm{~d}$ in culture $(A-C)$. On day 11, however $(D-F)$, all live cell staining with N-GluR1 is confined to synapses, defined by the presence of presynaptic synaptophysin stain $(F)$. Note that N-GluR1-induced antibody patching appears to cluster all the surface immunostaining at both day $4(A)$ and day $11(D)$ but leaves a significant portion of the total GluR1 signal, seen with the C-terminal antibody, unclustered $(B, E)$. 


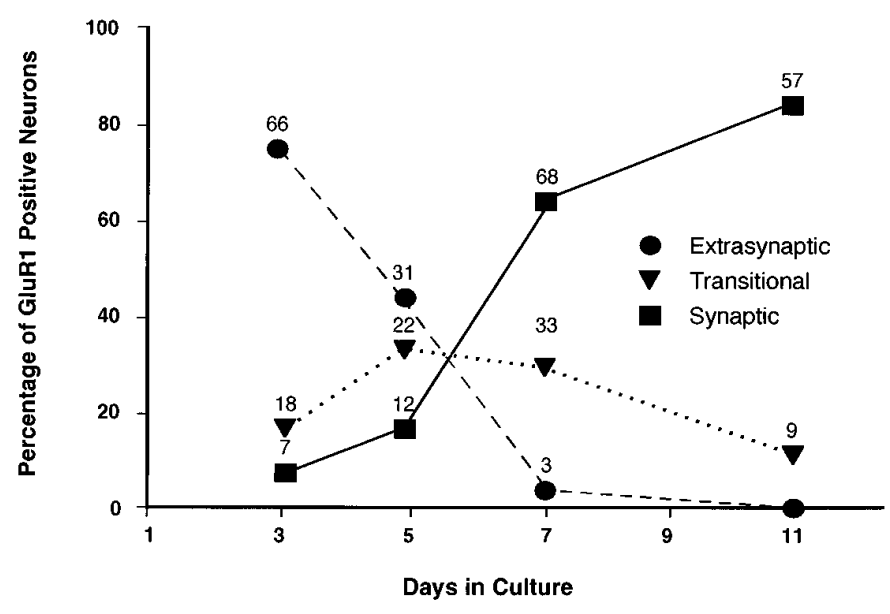

Figure 4. Time course of surface GluR1 redistribution in vitro. Synaptic clusters and extrasynaptic patches of GluR1 were visualized as described in Figures 2 and 3. GluR1-immunopositive neurons were categorized as either synaptic, extrasynaptic, or transitional on the basis of the following scheme. "Extrasynaptic" neurons averaged more than eight extrasynaptic patches and one or fewer synaptic cluster per major dendrite. "Synaptic" neurons averaged two or more synaptic clusters and two or fewer extrasynaptic patches per major dendrite. "Transitional" neurons fell between these two categories. Neurons were taken from a series of three platings. The total number of neurons at each point is listed above that point. For every neuron, the length of each major dendrite examined was usually $60 \mu \mathrm{m}$.
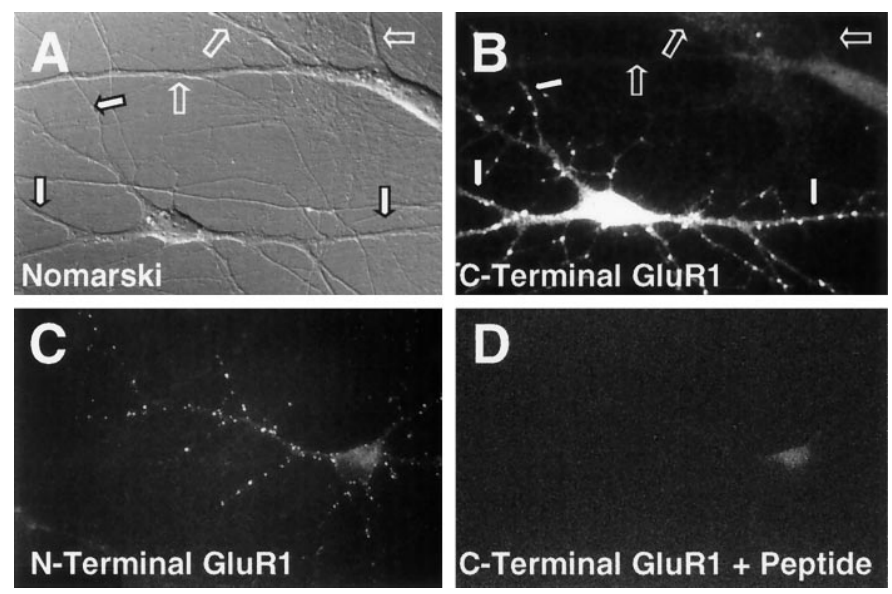

Figure 5. The diffuse dendritic staining for GluR1 is specific. For $A$ and $B$, an $11 \mathrm{~d}$ spinal cord culture was stained with Cy3-labeled C-GluR1, revealing two neurons, one of which is GluR1 immunopositive and one of which is GluR1 immunonegative. Note the differences in diff use dendritic stain between the immunopositive (closed arrows) and immunonegative (open arrows) neurons. The categorization of these cultured neurons as immunopositive and immunonegative is based on cell body and synaptic stain, and correlates well with in situ hybridization signal for GluR1 mRNA. In $C$ and $D$, a GluR1-immunopositive neuron from a $5 \mathrm{~d}$ culture, identified by live N-GluR1 stain $(C)$, shows minimal dendritic stain with Cy3-labeled C-GluR1 when the antibody has been preincubated with peptide (for comparison, see Fig. 3B,E). In all control experiments, neuronal cell bodies showed low-level, nonspecific staining, which did not extend into the dendrites.

synaptic GluR1 on their surfaces for up to 2 weeks in vitro, a time at which almost all neurons in mass cultures have suppressed extrasynaptic GluR1 expression. This was true even in neurons that had clusters of synaptic GluR1 (Fig. 6). Possible explanations for these results could lie in the density of either excitatory or
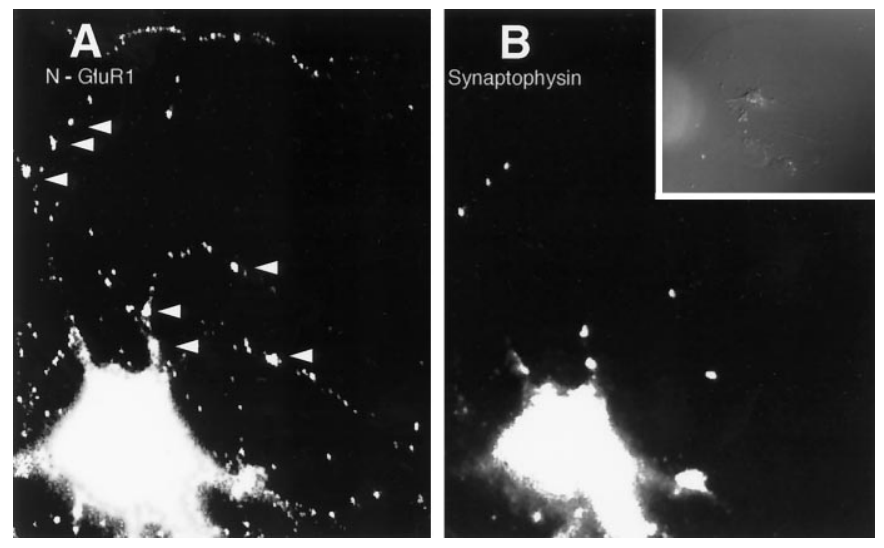

Figure 6. Lack of suppression of extrasynaptic GluR1 in island cultures. Island cultures containing isolated spinal cord neurons were grown for $10 \mathrm{~d}$. Under these conditions all synaptic contacts are autaptic. In $A$, the staining pattern of N-GluR1 continues to show extrasynaptic patches of GluR1 (arrowheads) despite autaptic clusters of GluR1 (arrows).
A

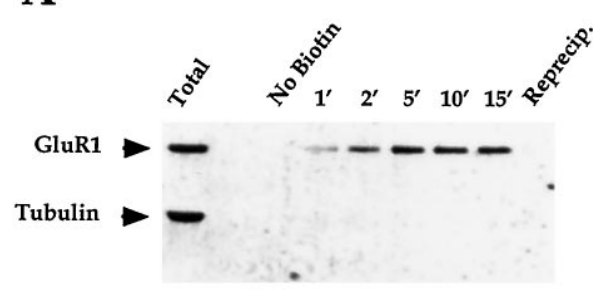

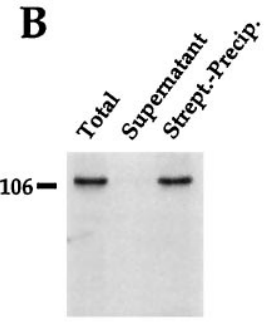

Figure 7. Time course and efficiency of biotinylation of GluR1 in cultured spinal cord neurons. Cultures of spinal cord neurons were biotinylated at $4^{\circ} \mathrm{C}$ with $1 \mathrm{mg} / \mathrm{ml} \mathrm{NHS-SS-biotin.} \mathrm{In} A$, cultures were exposed to the biotinylating reagent for different times, and the detergent soluble fraction of each culture was added to streptavidin-conjugated beads and incubated for $2 \mathrm{hr}$. The supernatant recovered from the precipitation of the 15 min-treated neurons was reprecipitated with streptavidin beads, and the additional streptavidin-precipitated material was loaded as well. All samples were loaded such that each lane represents $1 \%$ of the total material per plate. The gel was transferred to immobilon and probed with both C-GluR1 and anti-tubulin antibodies. In $B$, one plate of neurons was scraped into the biotinylating reagent, sonicated, spun at $14,000 \times g$ for 15 min, and resuspended in precipitation buffer including $0.2 \%$ SDS and $1 \%$ Triton X-100. A fraction of this was saved and loaded as total extract. The remainder was incubated for $2 \mathrm{hr}$ with streptavidin-conjugated beads. The supernatant, streptavidin-precipitated, and total extracts were loaded such that each lane represents $1 \%$ of the material from the plate. The gel was transferred and probed with the C-GluR1 antibody.

inhibitory synapses on neurons grown in isolation [compare Fig. 1 with Fig. 6 here, or compare Fig. 2 with Fig. 5 in O'Brien et al. (1997)]. Alternately, autaptic synapses may not be as proficient as heterotopic synapses in forming excitatory synapses. We suspect that some component of appropriate synaptogenesis may be limiting under these conditions.

\section{The half-life of surface GluR1 increases as neurons mature}

To correlate changes in receptor distribution with changes in receptor turnover, we used membrane-impermeant biotinylation, combined with streptavidin precipitation, to distinguish surface from subsurface pools of GluR1. Figure $7 A$ demonstrates that the biotinylation reaction proceeds quickly, peaking in $10 \mathrm{~min}$, and that all biotinylated GluR1 may be recovered by a single streptavidin precipitation. Moreover, virtually no tubulin is detected in 


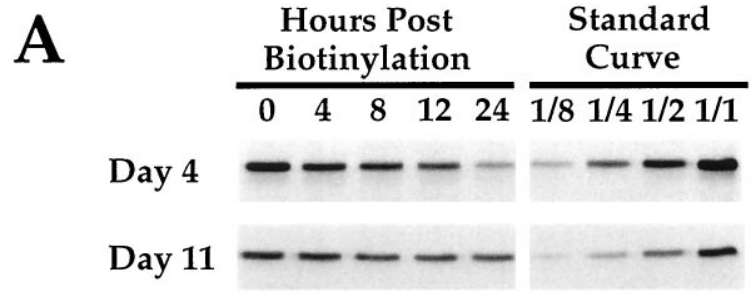

B

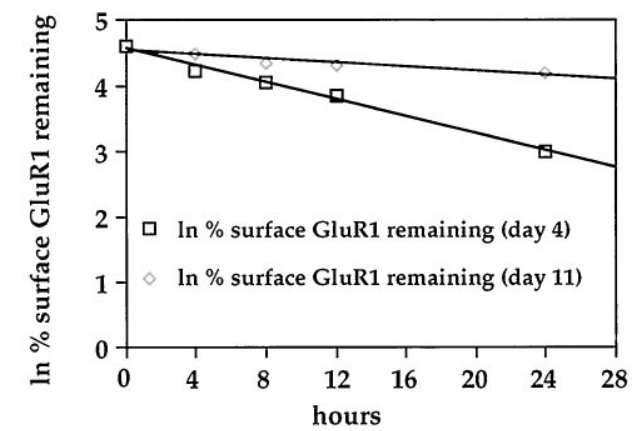

Day 4 Half-Life $=10.7 \mathrm{hrs}$

Day 11 Half-life $=43.3 \mathrm{hrs}$

Figure 8. Half-life of cell surface GluR1 in spinal cord neuronal cultures at day 4 and day 11 in vitro. Plates of spinal cord neurons were biotinylated at day 4 and day 11 and recultured for $0-24 \mathrm{hr}$, at which time cell extracts were harvested, sonicated, and frozen. Subsequently, these samples were thawed and incubated with streptavidin-linked beads, and the streptavidin-precipitated material was loaded onto gels $(A)$. A standard curve including serial dilutions of the $t=0$ streptavidin-precipitated material was included on each gel for purposes of quantitation. After transfer, gels were probed with the C-GluR1 antibody. In $B$, the natural $\log$ of the percent of remaining surface GluR1 was plotted against time, and half-lives were calculated from the regression slopes of the resulting lines. The results of the experiment in $A$ are shown.

the streptavidin-precipitated material, indicating that only cell surface proteins were recovered. To examine the efficiency of the biotinylation reaction, neurons were lysed in the presence of the biotinylating reagent, and membranes were prepared immediately from the lysed cells. After streptavidin precipitation of the detergent-soluble membrane extracts, no GluR1 could be detected in the supernatant (Fig. $7 B$ ), indicating that the biotinylation reaction was complete under these conditions. It should be noted, however, that fewer regions of GluR1 are accessible to biotin in the surface biotinylation experiments described below. Consequently, it is possible that the efficiency of surface biotinylation is not $100 \%$.

To determine the half-life of surface GluR1 before and after excitatory synapse formation, plates of spinal cord neurons from day 4 and day 11 in vitro were biotinylated, returned to the incubator, and solubilized at varying times after the initial biotinylation. Surface GluR1 was recovered with streptavidin and visualized by immunoblot (Fig. $8 A$ ). Quantitative analysis of the immunoblots was performed to determine the fractional decrease of biotinylated (surface) GluR1 over time (see Materials and Methods), from which the receptor half-life could be calculated (Fig. 8B). Table 1 shows that between days 4 and 11 in vitro, a time at which GluR1 goes from mostly extrasynaptic to almost entirely synaptic, the half-life of surface GluR 1 increased from $10.4 \pm 2.2$ to $30.5 \pm 12.7 \mathrm{hr}$ (paired $t$ test; $p<0.05$ ).

To determine the half-life of the total pool of GluRs, spinal cord cultures were metabolically labeled with ${ }^{35} \mathrm{~S}$-methionine.

\begin{tabular}{|c|c|c|c|}
\hline Experiment & Day 4 & Day 11 & $n$ \\
\hline GluR1 surface half-life & $10.4 \pm 2.2 \mathrm{hr}$ & $30.5 \pm 12.7 \mathrm{hr}$ & 3 \\
\hline GluR1 total half-life & $12 \pm 1.4 \mathrm{hr}$ & $31 \pm 4.2 \mathrm{hr}$ & 2 \\
\hline NGT half-life & $10.3 \pm 0.7 \mathrm{hr}$ & $13.2 \pm 2.4 \mathrm{hr}$ & 3 \\
\hline$\%$ GluR1 on surface & $32.5 \pm 4.5 \%$ & $68.6 \pm 12.9 \%$ & 5 \\
\hline
\end{tabular}

The means \pm SD for the half-lives of surface GluR1 and total GluR1 on days 4 and 11 are shown. A paired $t$ test demonstrated a significant increase in the half-life of surface GluR1 from day 4 to day $11(p<0.05)$. The half-life of the neuronal glutamate transporter (NGT) did not change significantly between day 4 and day 11 . Also shown are values for the percent of GluR1 on the surface of spinal cord neurons. There is a significant increase in the percent of GluR1 on the surface from day 4 to day $11(p<0.05)$.

Cell extracts were prepared at a number of time points after the initial ${ }^{35} \mathrm{~S}$-methionine pulse, and GluR1 was immunoprecipitated and separated by SDS-PAGE (data not shown). The metabolic half-lives of total GluR 1 at days 4 and 11 were calculated to be $12 \pm 1.4$ and $31 \pm 4.2 \mathrm{hr}$, respectively (Table 1 ). Thus, the incorporation of GluR1 into synapses correlates with an increase in its half-life. In contrast, the half-life of the neuronal glutamate transporter, which remains diffusely distributed on the neuronal surface between days 4 and 11 in culture (O'Brien et al., 1997), does not change (Table 1).

\section{The fraction of GluR1 on the cell surface increases as neurons mature}

As mentioned previously, immunocytochemical studies had indicated that there exists a sizable pool of intracellular GluR1 in cultured spinal cord neurons (Figs. 2-4). We again used surface biotinylation to determine the percentage of GluR1 that resides on the cell surface at different times in vitro. In these experiments surface GluR1 was biotinylated, precipitated with streptavidin, and compared with total GluR1 using quantitative immunoblotting (Fig. 9). We found that only $32.5 \pm 4.5 \%$ of the total GluR1 was located on the cell surface at day 4 , a time at which little synapse formation has taken place. By day 11, in contrast, $68.6 \pm$ $12.9 \%$ of GluR1 could be found on the cell surface. This represented a significant increase in the percentage of GluR 1 on the surface as neurons mature and GluR1 redistributes to synapses (Student's $t$ test; $p<0.05$ ). As mentioned above, these estimates of the size of the surface pool of GluR1 may be slightly high if the efficiency of surface biotinylation is actually less than the $100 \%$ our controls suggested.

\section{DISCUSSION}

To investigate the regulation of excitatory transmitter receptors during synapse formation in neurons from the CNS, we have studied cultured spinal cord neurons using various antibodies against GluR subunits. Previously, we found that synapse formation occurs over the course of $10 \mathrm{~d}$ in these cultures, beginning on day 2 (O'Brien et al., 1997). In the present study we have used an antibody that recognizes an extracellular domain of GluR1, N-GluR1, to study the distribution of surface receptors during this same period. Before synapse formation, GluR1 is distributed widely over the surface of dendrites in a form that is mobile and easily aggregated into patches by the addition of N-GluR1. Biotinylation studies suggest that at this time, the surface component represents approximately one-third of the total receptor pool, with the remaining two-thirds in the cell body and dendritic cytoplasm. Immunohistochemical studies also suggest the pres- 


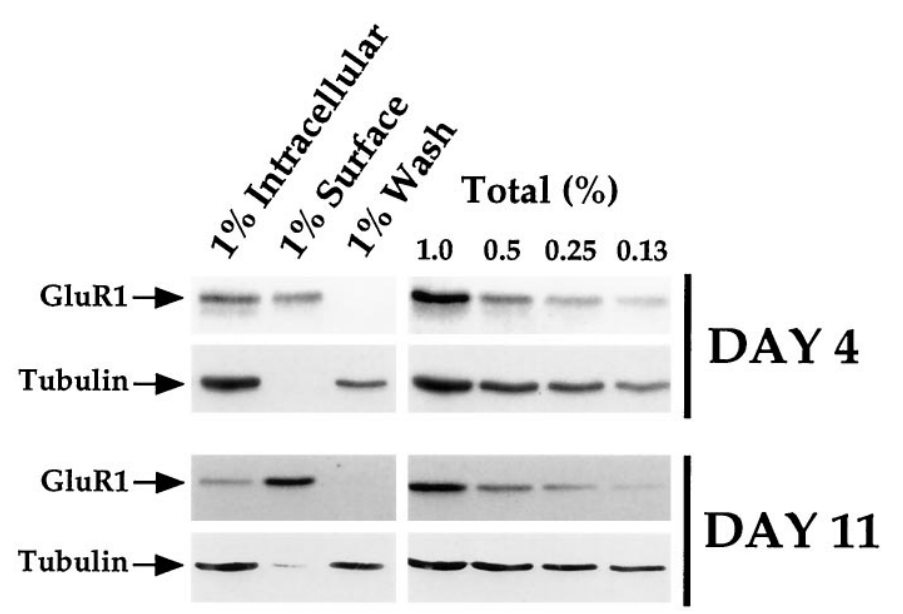

Figure 9. Determination of the fraction of GluR1 on the cell surface at day 4 and day 11 . Spinal cord neuronal cultures were biotinylated, harvested, and incubated with streptavidin beads. Samples of the total extract, streptavidin-supernatant (intracellular), streptavidin-precipitate (surface), and washes were saved and loaded, such that each lane represents protein from $1 \%$ of the plate. Serial dilutions of the total extract were also loaded for purposes of quantitation. The gels were transferred, probed with C-GluR1, stripped, and reprobed with anti-tubulin antibody. In each of five experiments, $<1 \%$ of the total tubulin was precipitated as a "surface" molecule.

ence of a significant cytoplasmic pool of dendritic GluR1 before synapse formation. As synapses form over the subsequent 2 weeks, surface GluR1 is gradually directed away from extrasynaptic sites and toward sites of appropriate cell-cell contact. During this same time period there is an increase in the percentage of total cellular GluR1 on the surface, although a substantial dendritic cytoplasmic pool remains. Whether the redistribution of GluR1 away from extrasynaptic sites is attributable to a directed insertion at synapses or to migration within the plane of the membrane is uncertain. Some conclusions can be drawn regarding the mechanisms leading to the redistribution of GluR1. First, synaptic activity had no effect on receptor redistribution. Spontaneous synaptic activity begins on day 3 in vitro and increases rapidly over the subsequent $7 \mathrm{~d}$ (O'Brien et al., 1997). Previous work showed that incubating cultures with TTX (Craig et al., 1994) or CNQX and APV (O'Brien et al., 1997), at concentrations sufficient to block all synaptic activity, had no effect on synapse formation. Our present study suggests that synaptic activity also plays no role in the redistribution of surface receptors. In contrast, neurons grown in island cultures, with a paucity of synaptic input, had no downregulation of extrasynaptic receptors. Therefore it seems that some quantitative aspect of synapse formation, independent of synaptic activity, causes both an increase in GluR1 at synaptic sites and a decrease at extrasynaptic sites. Perhaps a growth factor or cell adhesion molecule derived from the presynaptic neuron directs the redistribution of AMPA receptors to synapses during development. The absence of a significant effect of synaptic activity on receptor redistribution in cultured spinal neurons is in contrast to results observed at the neuromuscular junction where extrasynaptic AChR levels are regulated by electrical activity. AChRs reappear extrasynaptically after blockade of synaptic transmission or muscle denervation, a process that can be antagonized by chronic electrical stimulation (Lomo and Rosenthal, 1972; Berg and Hall, 1975a; Lomo and Westgaard, 1975).
Another aspect of synapse formation, shared both by spinal cord neurons and by the neuromuscular junction, is the stabilization of receptors at synapses. Using biotinylation techniques, we found that GluR1 receptor subunits on the cell surface have a half-life of $\sim 10 \mathrm{hr}$ at day 4 . By day 11 , however, the half-life of surface GluR1 increased to $\sim 30 \mathrm{hr}$, coincident with the aggregation of surface receptors at synapses. Very similar values were obtained for the half-lives of the total pool of GluR1, determined by pulse-chase experiments using ${ }^{35} \mathrm{~S}$-methionine as a label. The values obtained for GluR1 half-lives by these two methods are similar, suggesting that, as has been found in other cell-surface biotinylation studies (Volz et al., 1995), the biotinylation of surface molecules has little effect on GluR1 metabolism. The increase in surface GluR1 observed between days 4 and 11 in vitro is likely a consequence of both the increased half-life of surface GluR1, attributable to its stabilization at synapses, and to the increasing number of synapses in these cultures. Further work will be required to determine what fraction of synthesized GluR subunits ultimately reaches the cell surface and to elucidate the degradative pathways involved in their metabolism. Studies examining the surface expression and metabolism of other GluR subunits will also be of significant interest.

The current model for neurotransmitter receptor regulation during synaptogenesis has emerged largely from work at the neuromuscular junction. In this system, preexisting and mobile surface AChRs are trapped and stabilized at sites of nervemuscle contact under the influence of agrin, a basement membrane bound molecule (Bowe and Fallon, 1995). In a second step, the presynaptic nerve terminal directs the synthesis and insertion of locally formed receptors under the influence of ARIA (Falls et al., 1993), a molecule that may also initiate the synthesis of a novel receptor subunit. Third, nerve-induced electrical activity in the postsynaptic myotube causes a downregulation of extrajunctional receptors (Avila et al., 1989). In spinal cord cultures, the diffusely distributed population of surface GluR1 found before synapse formation could conceivably aggregate at synapses. Indeed, this possibility has been suggested by others who have detected the presence of extrasynaptic surface AMPA receptor subunits in both the hippocampus (Baude et al., 1995) and striatum (Bernard et al., 1997); however, direct proof for or against this theory is lacking. An alternative hypothesis, which we are currently testing, involves the directed insertion of preformed receptors at sites of synaptic contact. These receptors could be derived from the large intradendritic pool of receptors that we observed before and after synapse formation. These intradendritic receptors could either be associated with the extensive sarcoplasmic reticulum seen in the processes of many neurons (Spacek and Harris, 1997) or could be directly linked to the cytoskeleton. Whether this pool of subsurface receptors is eventually incorporated into synapses is unclear. Kharazia et al. (1996) recently observed GluR1 containing subsurface vesicles associated with the cytoplasmic face of many GluR1-containing cortical synapses. In contrast, Baude et al. (1995) failed to observe similar subsynaptic vesicles in the hippocampus. The disappearance of extrasynaptic receptors seen in our present study could be a reflection of either synaptic stabilization or localized insertion of GluR1, both of which could be subunit dependent. The future isolation and characterization of proteins involved in GluR clustering should help to clarify the molecular mechanisms underlying excitatory synaptogenesis in these neurons. 


\section{REFERENCES}

Anderson MJ, Cohen MW (1977) Nerve-induced spontaneous redistribution of acetylcholine receptors on cultured muscle cells. J Physiol (Lond) 268:757-773.

Avila OL, Drachman DB, Pestronk A (1989) Neurotransmission regulates the stability of acetylcholine receptors at the neuromuscular junction. J Neurosci 9:2902-2906.

Baude A, Nusser Z, Molnar E, McIlhinney RA, Somogyi P (1995) High resolution immunogold localization of AMPA type receptor subunits at synaptic and non-synaptic sites in rat hippocampus. Neuroscience 69:1031-1055.

Bechade C, Colin I, Kirsch J, Betz H, Triller A (1996) Expression of glycine receptor subunits and gephyrin in cultured spinal neurons. Eur J Neurosci 8:429-435.

Berg D, Hall ZW (1975a) Increased extrajunctional acetylcholine sensitivity produced by chronic post-synaptic blockade. J Physiol (Lond) 244:659-676.

Berg D, Hall ZW (1975b) Loss of alpha-bungarotoxin from junctional and extrajunctional acetylcholine receptors in rat diaphragm muscle in vivo and in organ culture. J Physiol (Lond) 252:771-789.

Bernard V, Somogyi P, Bolam JP (1997) Cellular, subcellular, and subsynaptic distribution of AMPA-type glutamate receptor subunits in the neostriatum of the rat. J Neurosci 17:819-833.

Blackstone CD, Moss SJ, Martin LJ, Levey AI, Price DL, Huganir RL (1992) Biochemical characterization of a non-NMDA receptor in rat brain. J Neurochem 58:1118-1126.

Bowe MA, Fallon JR (1995) The role of agrin in synapse formation. Annu Rev Neurosci 18:443-462.

Craig AM, Blackstone CD, Huganir RL, Banker G (1993) The distribution of glutamate receptors in cultured rat hippocampal neurons: postsynaptic clustering of AMPA specific subunits. Neuron 10:1055-1068.

Craig AM, Blackstone CD, Huganir RL, Banker G (1994) Selective clustering of glutamate and GABA receptors opposite terminals releasing the corresponding neurotransmitters. Proc Natl Acad Sci USA 91:12373-12377.

Ehlers MD, Mammen AL, Lau LF, Huganir RL (1996) Synaptic targeting of glutamate receptors. Curr Opin Cell Biol 8:484-489.

Falls DL, Rosen KM, Corfas G, Lane WS, Fischbach GD (1993) ARIA, a protein that stimulates acetylcholine receptor synthesis, is a member of the neu ligand family. Cell 72:801-815.

Frank E, Fischbach GD (1979) Early events in neuromuscular junction formation in vitro. Induction of acetylcholine receptors in the postsynaptic membrane and morphology of newly formed nerve-muscle synapses. J Cell Biol 83:143-158.

Hall ZW, Sanes JR (1993) Synaptic structure and development: the neuromuscular junction. Neuron 10:99-121.

Hollmann M, Heinemann S (1994) Cloned glutamate receptors. Annu Rev Neurosci 17:31-108.
Hollmann M, Maron C, Heinemann S (1994) $N$-glycosylation site tagging suggests a three transmembrane domain topology for the glutamate receptor subunit GluR1. Neuron 13:1331-1343.

Kharazia VN, Wenthold RJ, Weinberg RJ (1996) GluR1 immunopositive interneurons in rat neocortex. J Comp Neurol 368:399-412.

Killisch I, Dotti CG, Laurie DJ, Luddens H, Seeburg PH (1991) Expression patterns of $\mathrm{GABA}^{\mathrm{A}}$ receptor subtypes in developing hippocampal neurons. Neuron 7:927-936.

Lomo T, Rosenthal J (1972) Control of acetylcholine sensitivity by muscle activity in rat. J Physiol (Lond) 221:493-513.

Lomo T, Westgaard RH (1975) Control of acetylcholine sensitivity in rat muscle fibers. Cold Spring Harbor Symp Quant Biol 40:263-274.

Molnar E, McIlhinney RA, Baude A, Nusser Z, Somogyi P (1994) Membrane topology of the GluR1 glutamate receptor subunit: epitope mapping by site directed antipeptide antibodies. J Neurochem 63:683-693.

O'Brien RJ, Mammen AL, Blackshaw S, Ehlers MD, Rothstein JD, Huganir RL (1997) The development of excitatory synapses in cultured spinal neurons. J Neurosci 17:7339-7350.

Reiness CG, Weinberg CB (1981) Metabolic stabilization of acetylcholine receptors at newly formed neuromuscular junctions in rat. Dev Biol $84: 247-254$.

Roche KW, Raymond LA, Blackstone CD, Huganir RL (1994) Transmembrane topology of the glutamate receptor subunit GluR6. J Biol Chem 269:11679-11682.

Role LW, Matossian VR, O'Brien RJ, Fischbach GD (1985) On the mechanism of acetylcholine receptor accumulation at newly formed synapses on chick myotubes. J Neurosci 5:2197-2204.

Salpeter MM, Harris R (1983) Distribution and turnover rate of acetylcholine receptors throughout the junction folds at a vertebrate neuromuscular junction. J Cell Biol 96:1781-1785.

Salpeter MM, Marchaterre MR (1988) Distribution of extrajunctional acetylcholine receptors on a vertebrate muscle: evaluation by using a scanning electron microscope autoradiographic procedure. J Cell Biol 106:2087-2093.

Seeburg PH (1993) The Trends Neurosci/TIPS lecture. The molecular biology of glutamate receptor channels. Trends Neurosci 16:359-365.

Segal MM, Furshpan EJ (1990) Epileptiform activity in microcultures containing small numbers of hippocampal neurons. J Neurophysiol 64:1390-1399.

Spacek J, Harris KM (1997) Three-dimensional organization of smooth endoplasmic reticulum in hippocampal CA1 dendrites and dendritic spines of the immature and mature rat. J Neurosci 17:190-203.

Steinbach JH (1981) Developmental changes in acetylcholine receptor aggregates at rat skeletal neuromuscular junctions. Dev Biol 84:267-276.

Volz B, Orberger G, Porwoll S, Hauri H-P, Tauber R (1995) Selective reentry of recycling cell surface glycoproteins to the biosynthetic pathway in human hepatocarcinoma HepG2 cells. J Cell Biol 130:537-551. 